39. Dr. G. T. Whyburn: Concerning connected and regular point sets.

This paper will appear in full in an early issue of this Bulletin.

B. A. Bernstein, Secretary of the Section

\title{
BEQUESTS TO THE SOCIETY
}

At its meeting held on May 6, 1927, the Board of Trustees of the Society adopted the following resolution:

Resolved, that the Treasurer be, and hereby is, instructed to credit to endowment all bequests made to the American Mathematical Society except those specifically designated for other purposes.

Several members have already made provision for bequests to the funds of the Society. The specific action of the Trustees was taken in view of the suggestion of one of these persons that other members wishing to take similar action might know what disposition would be made of unspecified bequests. For such bequests, the following form, which is sufficient in any state, is suggested:

"I give and bequeath to the American Mathematical Society, a corporation incorporated under the laws of the District of Columbia, the sum of ..... dollars."

Still others have written into their wills bequests for specific purposes, such as prizes. Members who desire to make, such bequests are invited to consult the officers of the Society regarding the most urgent needs of mathematics in this country.

W. B. Fite,

Treasurer. 